\title{
Note on Projects for the Improvement of Sponge-Fisheries.
}

\author{
By \\ George Bidder. \\ For Summary see under title of preceding article. \\ A. Sponge-cultivation.
}

IN considering the experiments of Buccich (6) on propagation of sponges by cuttings, two main questions present themselves:-

(1) If a sponge be divided into many fragments, will the total increase of such fragments and their progeny be greater than the increase of the intact sponge and its progeny would have been in the same time; the conditions of water, \&c., being identical ?

(2) Are sponges, grown as recommended by Buccich, more or less favourably situated than those on the sea-bottom?

(1) The first of these questions I should, according to our present knowledge, answer in the negative. We have no evidence whatever as to the rate of growth of the sponge of commerce at Lesina, under natural conditions. So far as I am aware, there is no observation in the literature of the subject which throws any light whatever on the probable age of sponges of given size, their probable future rate of increase, or the dimensions at which increase stops.*

When, therefore, Buccich records that his cuttings grew to two or three times their size in the first year, we have no reason for supposing that an equal increase would not have taken place had they remained intact in the surface of the parent sponge. A priori, I should suppose that a greater increase would have taken place. For the life of a sponge depends on a most interesting system of hydraulic canals, on the mechanical perfection of which depends the quantity of its food. Each cutting contains only the fragment of such a system, broken into, with direction of currents confused or inverted, and pressure-chambers

* A discussion of the question of growth will be found in the Appendix. 
opened. Until growth has repaired these injuries, the cut fragment must necessarily be at a disadvantage, as compared with a complete sponge of its own size, ${ }^{*}$ and I am of opinion that the complete small individual is at a disadvantage as compared with the equal portion of a large and powerful sponge.

We have no knowledge of any causes to check the growth of a sponge, though it may be assumed (without positive proof) that they are subject to senile decay. But we have no knowledge that the tissues of a senile sponge undergo rejuvenescence when they are divided into fragments; and the observations of Buccich-that certain cuttings never grew at all, and that the growth was unequal-indicate slightly the more probable hypothesis that the fragment of an effete sponge is itself effete.

It is urged that misshapen sponges may thus be utilized. But it must be pointed out that misshapen sponges can still breed, and that there is no evidence how far the reproductive function is interfered with by the cutting process; I should myself expect such interference to be important. Buccich found 90 per cent. of his cuttings attain "marketable size" in seven years. Whether this is advantageous depends on the length of time taken by a self-sown sponge to attain "marketable size." If this be seven years also, then the method is profitable for misformed sponges; if it be only one year, then the quantity produced by natural reproduction would be greater than by the method of cuttings.

I know of no observations which favour the former hypothesis; and some siliceous sponges have been observed to grow to an equal size in a single season.

In view of the commercial importance of this question, it appears highly desirable that observations should be made as to the rate of growth of self-sown sponges. Until such are made, I cannot see that we have any reason to suppose that propagation by cuttings is in itself likely to increase the value of a sponge field.

(2) The above conclusion coincides nearly with that of Dr. von Marenzeller, in 1878. But the second question appears to have escaped his notice.

Briefly, I consider that the method of Buccich may possibly be made useful as a means of inducing sponges to grow on a more extended surface than the sea-bottom, and under more advantageous conditions.

It has been recognised among certain littoral sponges that gigantic specimens are generally found hanging from the under surface of

* In the Florida experiments it is recorded that this was the case. 
a rock, or floating body. * This has been observed for calcareous sponges on the floating frameworks set for oyster-spat in Holland (9), on the bottoms of ships in Naples harbour (9), on the under surface of a buoy at the Isle of Man (13), and may be verified to some extent even on the shore-rocks near the Plymouth Laboratory.

I am aware of no direct observations on this point with regard to any greater depth. But the same advantage, probably, there also attends an elevated position. Thus, Hyatt (5) says that "The sponges near Nassau lie ... . always in currents, sometimes running three or four miles an hour. .... Both of these conditions are essential to sponge growth, namely, a continuous renewal of aërated water, and a plentiful supply of food." And Rathbun (11) says of cuttings in Florida: "One was placed in a cave or bight, where there was little or no current, and its increase in size was very slight. The other specimens were placed in tide-ways, and have grown from four to six times their former bulk."

Now, where a current of water is flowing over a solid surface, a very slight increase in height from the surface means great increase in velocity of current. Buccich's method placed the cuttings from four to twelve inches above the sea bottom, and with their centres four inches apart, disposed on four parallel gratings separated from each other by the same distance. He appears to have dealt only with the small, fine, toilet sponge (7); but even so, I think the system capable of improvement. I consider great advantage might be obtained by inducing sponges to grow on hurdles rising some feet above the sea-bottom, and allowing a distance between the centres of four inches for cuttings, and twelve inches or more for grown sponges, with a distance between every two hurdles equal to their own height. I should experiment by ballasting and sinking a hurdle such as is used for a deer fence, preferably of enamelled iron; with (a) canes tied across it parallel to the bars, and (b) vertical tiles, hung in pairs on the bars. To these cuttings, or small sponges, might be attached; and I should try making the attachment with a needle and thread, using the method of Buccich as a control experiment. The cuttings on the canes would grow round them to form perforated spheres. These Marenzeller states to be of less value in the market, owing to the perforation, but I should imagine they would soon acquire a value of their own, as they would have no torn surface. These, also, as being exposed on all sides, would probably grow most rapidly. The cuttings on the tiles should become of the ordinary hemispherical type. It might be found that young sponges

* Cf., especially Vosmaer (9), where he points out the advantages to the sponge of a position where water flows freely round it. This was to some extent recognised, long ago by Grant fide Johnston (1). 
would sow themselves naturally on the tiles, rendering cuttings unnecessary.

It would be better if the hurdles were sunk rather in deeper water than that from which the sponges are taken, lest the cuttings should suffer from excess of light. I should cut the sponges in a wooden trough, holding enough water to cover the sponge. The advantages expected by the method would be :-

(1) Increase of the bearing area of the field.

(2) Removal of the sponges without injury, and with careful selection.

(3) Increase in the rate of growth, and in the maximum size.

(4) Improvement in shape of the sponges.

There is also a proposition given by Dr. von Marenzeller which deserves attention. Larger sponges are naturally of greater value, in proportion to their weight, than smaller sponges; and he points out that if two or three be attached closely together (misshapen specimens could be thus utilized) they will grow into one sponge.

In this case, also, I should suggest the use of the needle and thread to effect the attachment; and, from the biological point of view, there is little doubt of effectual union. But the possible existence of biological disadvantage, in total ultimate weight, cannot be estimated until we have some knowledge of the laws of growth in sponges; and the commercial advantage depends not only on this, but on market details, as to which I cannot find information. Probably the increase in value with size of Nassau sponges is far less than with those of the Adriatic.

It must be understood that these recommendations are based principally on general reasoning from what is known of the conditions of life in sponges. The direct experimental evidence bearing on the questions involved is slight, imperfect, and uncertain; the work done by Professor O. Schmidt (6) was brilliant; but it has remained incomplete, as he left it, for twenty-three years.

To avoid needless waste of capital, it is desirable to make a series of exact observations on the sponge of commerce with regard to the following points :-

(1) Rate of growth, and length of life, of sponges growing naturally on the sea-bottom.

(2) Do. do. of sponges attached with their natural bases to artificial trestles or hurdles.

(3) Do. do, of sponges raised from cuttings in either position.

(4) The size at which, in self-sown sponges and in cuttings, breeding commences. 
It must be remarked that it is difficult to see how any process of culture can be possible, unless private property in areas of sponge-fishery can be recognised and protected. [Cf. (1) (6)].

I see that Mr. Allen properly suggests the possibility that the deeper waters of the Bahamas may with advantage be exploited. If this be done, as in the Mediterranean, by divers without diving dresses, I would suggest encouraging them to try the use of water-spectacles. I am not aware that these have been ever used either for pearl-fishing or spongefishing; but, while every student knows that the imperfection of the submerged human eye can be corrected by convex lenses, there is a wide gulf of ignorance separating the student from the pearl-diver of the Indian Ocean. Probably any wholesale optician would supply spectacles of the required formula at the price of a few pence. The experiment might be worth instituting at Ceylon.

\section{B. Transport of Sponges from the Mediterranean to the Bahamas.}

If it were desired to transport European sponges alive to the Bahamas, I believe that this could be done. The sponge of commerce lives well in the Naples Aquarium, and I see no reason why it should not live in a suitably constructed tank on board a ship. In this way a number of individuals might be transported, and deposited in a space cleared from other sponges at a spot where the fishery is good, there to breed as they successively ripened. If it were practical from the nautical point of view, I should suggest the use of a closed wooden tank, with perforated sides, flat bottom, and pointed ends, to be towed behind the ship; just floating enough to keep a flagstaff out of water in case of accident. The sponges should be gathered with the pieces of rock to which they adhere, and these stones fixed firmly in the bottom of the tank. Before employing this method, it might be prudent to make aquarium experiments as to how far the high surface temperature of the seas traversed may prove deleterious to the sponges. Were such temperatures proved to be fatal, it would be necessary to use an aquarium inside the ship, artificially cooled.*

* Since the text was in type, I have been able to consult Lamiral's original account (3) of his unsuccessful attempt, in 1862, to acclimatise Syrian sponges on the French coast. He placed 150 sponges in six cubical boxes of $2 \mathrm{ft}$. $7 \mathrm{in}$. each way, six similar boxes being used for reservoirs to maintain a circulation (cooled with such ice as he could obtain), and the whole carried on the deck of a crowded packet-boat. This apparatus was quite inadequate; and his description leaves little room for doubt that the tanks were lined with bacterium slime from the very beginning of the voyage, and that the sponges hopefully planted on the French shore were in various stages of putrescence.

He records the bottom temperature at Tripoli in May as $19^{\circ} \mathrm{C}$. in ten fathoms of water ; his reservoirs on the journey rose to $23^{\circ} \mathrm{C}$. and $25^{\circ} \mathrm{C}$. An interesting account of the Syrian divers is given; besides useful details as to qualities of sponges, \&c.

NEW SERIES-VOL. IV. NO. 2.

* "On ignore quelle est au juste la durée de la vie des Eponges et la vitesse de leur accroissement; cependant, dès la troisième année, on peut revenir pêcher dans les lieux où elles avaient été précédement presque épuisées."-Lamiral, loc. cit. vol. viii. p. 329.

† Probably based on Schmidt's own statement: "Man sucht in der schon beschriebenen Weise dieselben Standorte Jahr für Jahr ab. . . . nicht nur die ausgewachsenen, sondern auch die kleineren Exemplare genommen werden." (Supplement der Spongien der Adria. tischen Meeres, 1864, p. 25.) At the time of writing the text I could not refer to Sehmidt's original papers; there is nothing to be added from them to the later account of his experiments given by Marenzeller. 
But if the transport were successful, and the sponges bred, it is very doubtful if any advantage would be gained. It must be regarded purely as an experiment in the dark; and I can see no means of forecasting its result, or testing it in any way, but by its completion. If the difference between the sponges is a true racial difference, then the race from the Mediterranean might possibly prove stronger than the race of the Bahamas, and supplant it, though the fact that the climates are different is against considering this as probable. There is, however, grave doubt whether the difference be due to deep-seated heredity. The sponges of America are considered no more than varieties of the Mediterranean species; and Professor Hyatt is of opinion (5) that the difference in quality between American and European sponges is due to the higher temperature of the American water, and to the coral sand. My own experience in calcareous sponges points to most remarkable plasticity in response to changes of environment, and it must be considered possible that, even if the imported sponges bred, their offspring would be indistinguishable from those always existing in the locality.

\section{Close time for Sponges.}

It is so common and so natural a tendency to consider the well-being of any fishery capable of improvement by the imposition of a close season, that it may be worth while recording simply that, according to F. E. Schulze (7), the toilet-sponge at Lesina breeds quite indifferently all through the year.

Professor Schulze is the leader of all modern work on sponges, and his observations were made on a plentiful series of sponges supplied by Signor Buccich. 


\section{APPENDIX.}

Rate of Growth in Sponges.-According to T. Lee (12), the fishermen of Nassau say that the young sponge reaches marketable size three months after its attachment. Lamiral (3), in his scheme for acclimatisation on the French coast, stated that exhausted fisheries are regenerated in three years. * O. Schmidt (6) "inclined to the opinion" that the growth of a self-sown sponge was no faster than that of one of his cuttings, which were found to take seven years to reach marketable size; -it is noticeable that before the experiment he had expected quicker growth (l.c. p. 776). The Florida fishermen-v. Rathbun (11)-contend that "the Florida sponges grow much more rapidly, and reach a fair size within a comparatively short period." The Florida cuttings increased "to from four to six times their bulk" in six months, but this growth was actually effected in two months, as "fully four months elapsed before they recovered from the injury done them in the cutting."

If this last be accurate, then a cutting of $2 \frac{1}{2}$ cubic inches, growing to five times its bulk in two months, attained a volume equal to a hemisphere over $3 \frac{1}{2}$ inches in diameter. Were it to proceed for the next two months at the same rate, we should have a hemisphere over 6 inches in diameter, which is more than marketable. Had the original $2 \frac{1}{2}$ cubic inches been produced at the same geometric rate, then a hemisphere of $1 \frac{1}{4}$ inches in diameter would have produced the six-inch sponge in six months.

We have no right to assume this constant geometric ratio, nor to reason elaborately from inexact statements about amputated fragments; but putting these observations with the assertions of the Nassau and Florida fishermen, there seems a balance of evidence against assuming in these localities a period much greater than a year before the self-sown sponge becomes marketable. The Levant variety, discussed by M. Lamiral, lives where the atlas shows a mean annual temperature of about $7^{\circ} \mathrm{F}$. below that of Florida, and the Adriatic variety, investigated by Professor Schmidt, at a mean temperature of about $7^{\circ} \mathrm{F}$. lower still; we have no right to assume that the rates of growth are identical. But since in the Adriatic the same grounds are said (8) to be fished mercilessly, mature and immature, year after year, $\dagger$ there seems to be great presumption against Schmidt's estimate; and this estimate was calculated from Buccich's cuttings, which I believe to have been unnecessarily

* "On ignore quelle est au juste la durée de la vie des Eponges et la vitesse de leur accroissement; cependant, dès la troisième année, on peut revenir pêcher dans les lieux où elles avaient été précédement presque épuisées."-Lamiral, loc. cit. vol. viii. p. 329.

† Probably based on Schmidt's own statement: "Man sucht in der schon beschriebenen Weise dieselben Standorte Jahr für Jahr ab. . . . nicht nur die ausgewachsenen, sondern auch die kleineren Exemplare genommen werden." (Supplement der Spongien der Adriatischen Meeres, 1864, p. 25.) At the time of writing the text I could not refer to Schmidt's original papers; there is nothing to be added from them to the later account of his experiments given by Marenzeller. 
injured by exposure to air, by the trepanned perforation, and by too close planting so as to choke each other.

The much-needed observations on the natural growth of commercial sponges could probably be best made by observing the seedlings on a small marked area, artificially cleared. Single sponges fixed on stones could also have labels attached with silver wire, and be examined periodically.

That the rapid period of growth suggested by the fishermen is not impossible, is shown by a few observations which have been made on calcareous and siliceous sponges. Vosmaer (9) calculated the giant Sycon on the oysterframes to grow 1 to $2 \frac{1}{2}$ inches in length in a fortnight, and (10) found the bud of a Tethya in a month as large as its mother, $\frac{4}{5}$ inch in diameter. Bowerbank (4) quotes H. Lee, that in the Brighton Aquarium Hymeniacidon formed in five months a crust 1 foot in diameter. Of this sponge and of Halichondria numerous large crusts may be observed in spring on the rocks near Plymouth Laboratory; they appear rarely to survive the summer, and Johnston (1) states that many allied species are annual. Carter (2) found Spongilla, at Bombay, grow over a surface two or three feet in circumference in nine months; and states that specimens growing on straw in the water reached a thickness of half-an-inch in a few days, before the straw in the water had changed colour.

The growth of horny sponges may easily be much slower than in these instances, but as yet I know of no reason to assume so.

\section{REFERENCES TO QUOTATIONS.}

1. Johnston, G. (1842).- “History of British Sponges and Lithophytes," p. 92 and p. 124.

2. Carter, H. J. (1849).-Annals and Mag. Nat. Hist. pp. 95 and 96.

3. Lamiral, E. (1861-1863).-Bull. Soc. d'Acclim. Paris, vol, viii. p. 327 ; vol. ix. p. 641 ; vol. x. p. 8.

4. Bowerbank, J. S. (1874). - " Monograph of British Spongiadæ," vol. iii. p. 339.

5. Hyatt, A. (1875 and 1877).-Mem. Boston Soc. Nat. Hist. vol. ii. quoted here from "U.S. Fish. Comm.," "Fishery Industries" (4to.), Sect. i. pp. 845, 846.

6 Marenzeller, E. von (1878).-Verhandlung der K. K. Zool. Bot. Gesellschaft in Wien, quoted here from translation in "U.S. Fish. Comm. Report" (8vo.), 1879 , p. 771, et seqq.

7. Schulze, F. E. (1879).-Zeitschr. wiss Zool. vol. xxxii. p. 617 and p. 642.

8. Faber, G. L. (1883).-- "Fisheries of the Adriatic," p. 96.

9. Vosmaer, G. C. J. (1884).-Mitth. Zool. Stat. Neapel, vol, v. pp. 486 and 487.

10. Vosmaer, G. C. J. (1887).- “ Bronn's Klass. u. Ord. d. Spongien,” p. 440.

11. Rathbun, R. (1887).- “U.S. Fish. Comm., Fishery Industries" (4to.), sect. v. vol, ii. p. 832.

12. Lee, T. (1889).- “U.S. Fish. Comm., Report of Comm. for 1886," p. 664.

13. Browne, E. T. (1894).-Trans, Liverpool Biol. Soc. vol, viii. p. 45.

It will be seen from this list how greatly I have been aided in compiling these notes by the most valuable publications of the United States Commission of Fish and Fisheries. 